Article

\title{
Investigating the Effect of a Mixed Mycorrhizal Inoculum on the Productivity of Biomass Plantation Willows Grown on Marginal Farm Land
}

\author{
Thomas Joseph Pray ${ }^{1}$, Werther Guidi Nissim ${ }^{2}$, Marc St-Arnaud ${ }^{1}$ and Michel Labrecque ${ }^{1, *}$ \\ 1 Biodiversity Centre, Institut de Recherche en Biologie Végétale, Université de Montréal and Jardin \\ Botanique de Montréal, Montréal, QC HIX 2B2, Canada; tjpray@gmail.com (T.J.P.); \\ marc.st-arnaud@umontreal.ca (M.S.-A.) \\ 2 Department of Agrifood Production and Environmental Science, University of Florence, \\ 4,50121 Firenze, Italy; werther.guidinissim@unifi.it \\ * Correspondence: michel.labrecque@umontreal.ca; Tel.: +1-514-872-1862
}

Received: 28 February 2018; Accepted: 30 March 2018; Published: 4 April 2018

\begin{abstract}
Inoculation with mycorrhizal fungi, proven mediators of soil fertility, has great potential in agricultural and silvicultural systems. This is particularly true in short-rotation coppices (SRCs), where questions of food displacement and fertilization are causes of concern for researchers and policy makers. We set out to thoroughly test if current inoculation methods, coupled with reduced fertilization, can demonstrate a growth benefit in SRC willows on marginal lands. Roughly 21,600 Salix miyabeana Seeman ('SX61' and 'SX64') were planted in a hierarchical design with inoculation treatments randomized first, cultivars randomized second, and fertilization treatments randomized third. This process was repeated across three fields of different marginal soil type (which, in our experiment, were given the descriptive names Sandy, Rocky, and Dry). The inoculum species, Rhizoglomus irregulare Błaszk., Wubet, Renker \& Buscot Sieverd., G.A. Silva \& Oehl and Hebeloma longicaudum (Pers.) P. Kumm., were chosen as they are most likely to be commercially available, and because they represent both arbuscular and ectomycorrhizal inoculum types. Growth was measured over 2.5 years, or three growing seasons. Fertilization treatment (75 kg/ha Nitrogen), however, was only applied during the second growing season. Our results conclusively showed no benefit from mycorrhizal inoculation across fields that exhibited significantly different growth rates, as well as significant differentiation from fertilization.
\end{abstract}

Keywords: mycorrhizal fungi; willow; inoculation; agricultural field experiment; rhizospheric soil

\section{Introduction}

Growing short-rotation coppiced (SRC) willows for energy purposes is particularly promising on agriculturally marginal land. Such land would neither come as a sacrifice to pristine, old-growth wilderness, nor would it have a significant impact upon food production, as much of this marginal land has become, or is becoming, unviable within the current competitive agricultural marketplace [1]. However, the main driver of efforts to develop biomass plantations, global warming, can also fuel concerns about fertilizer use [2]. In general, SRC willows can be grown on many types of agricultural land (though wetter land is much better than dry) [3,4]. Due to high biomass yields though, they remove nutrients at a high rate [5]. This means that poor sites are not suitable for SRC cultivation unless fertilizers are supplied. A relevant study showed that fertilizer represents up to $10-20 \%$ of the cost of production over several rotations of a willow SRC crop [6]. Estimates based on nutrient off-take measurements vary between 50-130 kg N, 60-83 kg K, and 8-16 kg P per hectare per year for willow SRC, although farmers generally only need to add nitrogen $(\mathrm{N})$ over the first several years, 
as potassium $(\mathrm{K})$ and phosphorus $(\mathrm{P})$ usually build up excessively in farm soil [7]. This paper addresses whether the central challenge of fertility that arises with SRC farming in a carbon-negative way on marginal land could be addressed or mitigated by inoculation with mycorrhizal fungi.

Arbuscular mycorrhiza (AM), which penetrate the root cells of their host plant, and ectomycorrhiza (EM), which interact just as intimately with their host plant but through a form of root interface that does not penetrate cells, are the two main types of mycorrhizal fungi (e.g., [8]). In exchange for the sugars that the plant produces, both AM and EM provide nutrients harvested from surrounding soil (particularly those trapped in mineral form or difficult-to-degrade organic molecules) with their extensive fungal networks and specialized degradation enzymes $[9,10]$. There is also extensive evidence of AM and EM providing their hosts with protection from disease and aiding with water stress during droughts [11-13].

Biomass shrub willows-though small and with multiple stems instead of a single trunk-are nevertheless a tree species in the genus Salix L., and are typically found with EM symbionts in samples of their roots and rhizosphere (the narrow soil zone under the influence of roots) [14-16]. Salix species, however, have been found to be associated with both EM and AM (separately or at the same time) [17-20]. Minor association with AM cannot be ignored, as some evidence suggests that mycorrhiza can provide significant benefits for their host, even at low levels of root colonization [21,22].

Because agricultural land (or marginal, formerly agricultural land) does not typically have a diverse collection of trees growing on it, researchers have conducted experiments inoculating trees with mycorrhiza, reasoning that the specific EM species that would colonize biomass willows could be missing [23]. Similarly, as agricultural land is often exhausted of organic carbon and repeatedly left barren of plant hosts (when crops are harvested in late summer or fall), even AM, that could use crop plants as hosts, might be low in number and/or diversity [24,25]. Some experiments showed a benefit from inoculation, but many others were inconclusive [26-30]. The same is true for experiments specifically using Salix (or closely related Populus L.) and AM or EM inoculum [31-33].

In most of these studies, the controlled conditions used are significantly different from what willow growers will actually encounter in their fields. Even when young trees were planted into natural settings in some of these experiments, the seedlings were first raised in containers. This means that the control conditions, with completely sterile potting soil, could stunt the trees' early growth, and therefore do not reflect a natural control with a random mix of native mycorrhiza. Experiments with sterile control soils, and sterile soils plus one or more inoculum species throughout the measurement time period, while valuable for basic research, are inherently limited. Agricultural activities almost never deal with sterile soils, so for practical purposes, farmers and agricultural researchers need to know what their treatments do in relation to unsterile controls.

This study addresses the sterile control problem by planting directly into intact farm soil. This is possible in practical terms because willow cuttings do not need to be started in pots, and in theoretical terms because of the sheer number of willow cuttings planted. The myriad of combinations of native mycorrhiza, as well as of plant pathogens, etc., that would threaten a smaller experiment with too many confounding variables, are better dealt with through replication across large fields. If a few willows are negatively affected by small areas of soil with disease pathogens, or conversely if a few willows have increased growth due to a small area of particularly beneficial mycorrhiza, their growth measurements will not significantly shift the mean results from the many more growth measurements we were able to take through a field-scale investigation. Furthermore, the high variability in the growth of plants in fields that are naturally patchy in soil structure and nutrient concentration can be accounted for statistically with enough data points from several different blocks. This "random" variation was part of our ANOVA models, and our field sizes allowed us to do this. Biomass farmers, and those who advise farmers, should take note of this study's results, as they relate closely to real-world conditions. Even the equipment used to set up and implement the experiment was consistent with modern farming realities.

If the use of such energy intensive products as fertilizers can be limited through mycorrhizal inoculation, and likewise marginal agricultural land can be better taken advantage of, then biofuel 
grown with carbon taken from the atmosphere would inarguably represent a net climate benefit. Knowing whether inoculation is effective or not is a key step for this industry, and more generally, for those working in agriculture and silviculture. Our experiment aimed to take this step: it tested whether or not a mycorrhizal inoculant can have a positive effect on the growth of SRC willows. Furthermore, our experiment was designed extremely robustly, testing the inoculants effect across two different cultivars of willow in three different marginal field-types, and both with and without nitrogen fertilization.

\section{Materials and Methods}

\subsection{Experimental Design}

Three similarly designed experimental fields of $108 \mathrm{~m} \times 43.2 \mathrm{~m}$, or $\sim 4670 \mathrm{~m}^{2}$ each, were established in early June of 2010 at three sites on the Allard family farm (Agro Énergie Inc., Saint-Roch-de-1'Achigan, QC, Canada $\left(45^{\circ} 51^{\prime} 00^{\prime \prime} \mathrm{N}, 73^{\circ} 36^{\prime} 00^{\prime \prime} \mathrm{W}\right)$. The farm is $\sim 60 \mathrm{~m}$ above sea level, flat and open, but sparsely wooded at the edges. It lies within the St. Lawrence River watershed, $\sim 25 \mathrm{~km}$ north-northeast of Montreal, QC, Canada. A different soil type defines each experimental field (details are summarized in Table 1). One location, referred to in this paper as the Sandy field, is almost pure sand, with a low $\mathrm{pH}$ of 6 . Another, named Dry field, is sandy-loam with a close to neutral $\mathrm{pH}$ of 7 . The last consists of silty-loam, with a high $\mathrm{pH}$ of 8 , but with $\sim 30 \%$ of the surface covered with small and medium sized rocks $(\sim 1-5 \mathrm{~cm})$ (therefore named Rocky field). Fields had been cultivated in the past with the standard North American rotation of corn and soybeans (corn most recently), but the Sandy field had also been periodically planted with carrots before that.

Table 1. Characterization of the three field sites, including a soil analysis at two depths.

\begin{tabular}{|c|c|c|c|c|c|c|c|c|}
\hline Depth & $\mathrm{pH}$ & Nitrate & Phosphorus & Organic Matter & Clay & Silt & Sand & Soil Type \\
\hline \multicolumn{9}{|c|}{ Dry Field $\left(45^{\circ} 49^{\prime} 31^{\prime \prime} \mathrm{N}, 7^{\circ} 37^{\prime} 29^{\prime \prime} \mathrm{W}\right)^{1}$} \\
\hline$(0-20 \mathrm{~cm})$ & 7.1 & $5.77 \mathrm{ppm}$ & $130 \mathrm{~kg} / \mathrm{ha}$ & $4.0 \%$ & $21.0 \%$ & $40.9 \%$ & $38.1 \%$ & Medium loam \\
\hline$(20-40 \mathrm{~cm})$ & 7.3 & $7.35 \mathrm{ppm}$ & $81 \mathrm{~kg} / \mathrm{ha}$ & $3.9 \%$ & $19.9 \%$ & $32.7 \%$ & $47.4 \%$ & Edging towards sandy \\
\hline \multicolumn{9}{|c|}{ Rocky Field $\left(45^{\circ} 49^{\prime} 38^{\prime \prime} \mathrm{N}, 73^{\circ} 37^{\prime} 36^{\prime \prime} \mathrm{W}\right)^{2}$} \\
\hline$(0-20 \mathrm{~cm})$ & 7.9 & $6.87 \mathrm{ppm}$ & $63 \mathrm{~kg} / \mathrm{ha}$ & $3.5 \%$ & $29.5 \%$ & $39.2 \%$ & $31.3 \%$ & Medium loam \\
\hline$(20-40 \mathrm{~cm})$ & 7.9 & $5.77 \mathrm{ppm}$ & $39 \mathrm{~kg} / \mathrm{ha}$ & $2.8 \%$ & $24.1 \%$ & $43.5 \%$ & $32.4 \%$ & Edging towards clay \\
\hline \multicolumn{9}{|c|}{ Sandy Field $\left(45^{\circ} 49^{\prime} 32^{\prime \prime} N, 73^{\circ} 37^{\prime} 04^{\prime \prime} W\right)^{3}$} \\
\hline$(0-20 \mathrm{~cm})$ & 6.0 & $5.35 \mathrm{ppm}$ & $256 \mathrm{~kg} / \mathrm{ha}$ & $2.1 \%$ & $2.5 \%$ & $10.4 \%$ & $87.1 \%$ & Loamy sand \\
\hline$(20-40 \mathrm{~cm})$ & 6.1 & $5.91 \mathrm{ppm}$ & $192 \mathrm{~kg} / \mathrm{ha}$ & $2.0 \%$ & $3.4 \%$ & $6.8 \%$ & $89.8 \%$ & $\begin{array}{l}\text { Very close to pure } \\
\text { sand }\end{array}$ \\
\hline
\end{tabular}

${ }^{1}$ Defining qualitative features: heavily drained with a $0.5 \mathrm{~m}$ deep ditch along its west side and a $2 \mathrm{~m}$ deep channel along its south side. ${ }^{2}$ Defining qualitative features: $\sim 30 \%$ of its surface covered with small and medium sized rocks $(\sim 1-5 \mathrm{~cm}) .{ }^{3}$ Defining qualitative features: far removed from any drainage, it often had standing water for a week at a time after any rainfall, between the field and the forest bordering its south side and the southern half of its east side.

The experimental design was a modified split-plot design and had twelve full blocks repeated in each field. In this hierarchical design, inoculation treatments were randomized before cultivar, and fertilization treatments were randomized last. Local soil conditions and weather determined our partner farmer's best practices for preparing a weed-free, flat, and loose soil bed (a mix of plowing and disking). Small cuttings ( $\sim 30 \mathrm{~cm}$ long, and $\sim 1-2 \mathrm{~cm}$ thick) of two cultivars of willow, Salix miyabeana Seeman 'SX64' and 'SX61' were planted. Planting was done using a modified 3-row cabbage planter. Rows were $1.8 \mathrm{~m}$ apart, and willows were planted every $36 \mathrm{~cm}$, for a density of 16,103 trees per hectare. Flagged stakes marked every $18 \mathrm{~m}$, showing the edges of each experiment block $(6 \times 12$-row-wide blocks running down each half of the field, for 12 in total in each field-see Supplementary Material, Figure S1 for diagram). The modified aspect of the split-plot design came with the randomization of the cultivar. Instead of being randomized with each block, the random selection from the first block was continued for the entire length of the field, in order to facilitate timely and accurate planting 
at this large scale (again, see Supplementary Material, Figure S1 for diagram). The three farmers sitting on the planter were informed about which of the two willow types to feed into the rotating planter cylinders at the beginning of each new group of three rows. However, during planting, water delivery of the inoculant was turned off and on by hand as the planter stopped and started each block section, thus allowing a true randomization between each experimental block. Smaller flags on wire stakes subdivided the twelve blocks at $9 \mathrm{~m}$ (or six-row) intervals, but these subdivisions directed nitrogen fertilization, which was not applied until the second growing season (when it was applied by hand, due to the relatively small size of each treatment plot-see next paragraph for application rates). Therefore, during the first year each experimental block had four treatment subplots within them, which then became eight treatment subplots within each block from the second year on Similar blocks, albeit with a different randomly assigned treatment pattern, were set up in the three different fields.

Inoculation was done using a mixed inoculum of AM and EM fungi, provided by BioSyneterra Solutions Inc. (L'Assomption, QC, Canada). It was delivered via a water-suspension to each cutting at planting as $\sim 350$ propagules of the AM and 250 of the EM in $50 \mathrm{~mL}$ of water. The AM strain used was a Rhizoglomus irregulare (Błaszk., Wubet, Renker \& Buscot) Sieverd., G.A. Silva \& Oehl DAOM197198 [34,35]) from Pont Rouge, QC, Canada. The EM was a proprietary Hebeloma longicaudum (Pers.) P. Kumm. Viability of the inoculum was checked by taking a sample of the inoculum suspension on the day of planting, and inoculating several potted willows in autoclaved farm soil. Viability was qualitatively confirmed the following day with root staining and microscopic visualization of AM and EM structures, as well as with macroscopic identification of EM fructifications. Some 7200 cuttings were planted on each site, for a total of 21,600 plants. The experiment ran for two and a half years (through three growing seasons). Only during the second growing season did half of the trees receive nitrogen fertilization (75 kg/ha N, as pelleted chicken feather compost, scattered by hand in May).

\subsection{Sampling and Measurements}

Before planting had taken place, a baseline soil analysis was conducted. Soil was collected using a $1000 \mathrm{~cm}^{3}$, screw-boring hand sampler, combining seven samples taken from a diagonal line across each field. Two depths were sampled, 0-20 cm and 20-40 cm. All of the soil from each sample type was mixed thoroughly. A subsample was then taken back to the laboratory and air dried for chemical analysis using recommended methods [36]. Total nitrogen was measured using Kjeldal's method. Total phosphorus was extracted with nitric-perchloric acid or stannous chloride (for the sludge), and measured using plasma emission spectroscopy. Potassium, calcium, and magnesium were extracted with $\mathrm{NH}_{4} \mathrm{Ac}$, and analyzed by atomic absorption. Metals were extracted with nitric or hydrochloric acid, and their dosage was done using ICP (Inductively Coupled Plasma) [37].

We measured the height of the longest stem, its diameter at a distance of $10 \mathrm{~cm}$ from the ground, as well as the total number of stems, in order to assess shrub growth. Growth measurements were taken on every other tree along the middle row of the three-row treatment groups in early November, 2010. This meant that 16 trees were measured in each treatment group. With four treatment groups during the first year and 12 blocks repeated in each field, that totaled 2304 trees measured (the actual total was slightly lower as one block within the Sandy field was not measured in the first year, due to excessive mortality in that block, presumably as roots had not developed enough to compensate for the higher drainage in an almost $100 \%$ sand patch).

At the end of the second growing season (early December 2011), a total of 1152 trees were measured for growth, with 576 also selected randomly to be cut and weighed. A representative 2-3 kg of stem pieces (without leaves) were further subsampled from each field to measure moisture percentage. Although a block in the Sandy field had been dropped from the analysis in the first year due to the aforementioned high mortality, it was kept during the second year. This was because many of the trees that had died were actually concentrated in the middle of the block, and there were 
enough left to give an accurate representation of all the treatments with the addition of an increased fertilization subdivision.

At the end of the third growing season (late November 2012), two trees per treatment subgroup per block were measured and weighed (a total of 288 trees).

Thirty-six whole root samples were also dug up and collected in late October, 2010, after the first growing season; these consisted of three replicates of the twelve treatment combinations then in place (randomly chosen from the ten trees in the middle of each treatment group, within three randomly chosen blocks in each field). Because nitrogen fertilization was not applied until the second season, the twelve treatment combinations consisted of the two willow cultivar types in each of the three fields, inoculated and not. After shaking off unattached or excess soil, each plant's root system was separately bagged and stored at $-30^{\circ} \mathrm{C}$ in the laboratory's freezers the same day.

Root systems were later thawed and vigorously rinsed and agitated by hand in distilled water. The dirty rinse water was then allowed to settle, and the sediment was set aside and refrozen as 36 rhizospheric soil samples. After cutting up the roots into $1 \mathrm{~cm}$ pieces, they were well mixed and further homogenized (with a washed and sterilized commercial food-beverage blender in milli-Q/0.1TE buffer solution (Black \& Decker, Montréal, QC, Canada) and frozen as 36 root samples for the next molecular analysis steps.

\subsection{Molecular Fungal Community Analysis}

DNA from the first-year's 36 root and 36 rhizosphere samples was extracted using a MoBio Laboratories PowerSoil Extraction kit (MoBio Laboratories Inc., Carlsbad, CA, USA) according to the manufacturer's instructions, except that instead of the standard homogenization and lysis step, an MP Biomedicals FastPrep machine (MP Biomedicals Inc., Solon, OH, USA) at setting 4 was used for $25 \mathrm{~s}$ and six repetitions.

For cloning-sequencing, all replicates of both willow cultivars were pooled together by field and, inoculation treatment. The DNA extracted from rhizospheric soil was used to look for AM while DNA from root samples to look for EM since preliminary efforts revealed a tendency of the AM specific primers (AML1/AML2 [38]) to amplify willow DNA, attempts were made to detect both AM in the DNA extracted from rhizospheric soil, and EM in the DNA of the root samples. Conversely, in order to look for EM, universal fungal primers (ITS1F/ITS2 [39]) were used, since no EM fungi-specific primer was available. A search for AM was undertaken in both root extracts from the Sandy field and the rhizospheric soil extract, as soil extracts had not produced any AM sequences. All of this left six pooled samples for AM PCR-cloning and six for EM PCR-cloning.

A nested PCR reaction was run with samples used for AM detection. The initial PCR used the primer pair NS1/NS41 in a $25 \mu \mathrm{L}$ reaction with reagents from the MoBio PCR CoreKit (MoBio Laboratories Inc., Carlsbad, CA, USA). Initial denaturation was at $94{ }^{\circ} \mathrm{C}$ for $3 \mathrm{~min}$, followed by 30 cycles of $94^{\circ} \mathrm{C}$ for $45 \mathrm{~s}, 55^{\circ} \mathrm{C}$ for $1 \mathrm{~min}$, and $72{ }^{\circ} \mathrm{C}$ for $1 \mathrm{~min}$ (modified from [40]). The reaction ended with $10 \mathrm{~min}$ at $72{ }^{\circ} \mathrm{C}$ One microliter of product from this first PCR was then amplified in a second $25 \mu \mathrm{L}$ reaction using the AML1/AML2 primer pair. Initial denaturation was at $94{ }^{\circ} \mathrm{C}$ for $3 \mathrm{~min}$, followed by 30 cycles of $94{ }^{\circ} \mathrm{C}$ for $30 \mathrm{~s}, 58^{\circ} \mathrm{C}$ for $45 \mathrm{~s}$, and $72{ }^{\circ} \mathrm{C}$ for $45 \mathrm{~s}$, and ending with $10 \mathrm{~min}$ at $72{ }^{\circ} \mathrm{C}$ [40]. Eppendorf MasterCycler Pro thermocyclers (Eppendorf Canada Ltd., Mississauga, ON, Canada) were used, and PCR products visualized on 1\% agarose gels, according to the directions for Biotium's GelRed dye (Biotium, Inc., Fremont, CA, USA) and BioRad's Molecular Imager Gel Doc XR (Bio-Rad Laboratories, Hercules, CA, USA).

The samples used for EM detection were amplified in a single step using the same MoBio reagents (MoBio Laboratories Inc., Carlsbad, CA, USA) and the primer pair ITS1F/ITS2. Initial denaturation was at $94{ }^{\circ} \mathrm{C}$ for $3 \mathrm{~min}$, followed by 30 cycles of $94{ }^{\circ} \mathrm{C}$ for $45 \mathrm{~s}, 60{ }^{\circ} \mathrm{C}$ for $1 \mathrm{~min}$, and $72{ }^{\circ} \mathrm{C}$ for $1 \mathrm{~min}$ (modified from [41]). The reaction ended with $10 \mathrm{~min}$ at $72{ }^{\circ} \mathrm{C}$. The same thermocyclers and visualization method were used as described above. 
PCR products were cloned using a TOPO TA Cloning Kit (Invitrogen, Carlsbad, CA, USA) for sequencing, from Life Technology, according to the manufacturer's directions. Forty-eight clones for each sample were reamplified, and the products sequenced, at McGill University and Génome Québec Innovation Centre in Montreal, QC, Canada, using the common Sanger-sequencing method.

Sequences were grouped by CD-HIT (http://weizhongli-lab.org/cd-hit/) into operational taxonomic unit (OTUs) of $98 \%$ similarity. One representative sequence from each OTU group was then randomly selected for analysis using the BLAST search tool in the National Center for Biotechnology Information (NCBI) database. Only OTUs that were matched with AM organisms were tabulated (the $18 \mathrm{~S}$ gene is a highly conserved region and the AML1/AML2 primer pair is known to amplify other eukaryotic organisms as well).

\subsection{Data Analysis}

A full-factorial ANOVA was performed on the measured growth data. Growth is presented in this paper as stem basal area per hectare (SBA m²/ha) (modified from [42]). We determined SBA by calculating transectional stem areas from diameter measurements, multiplied by mean stem number, and then divided by the average area of land occupied by one willow (in hectares). SBA was calculated for each measured tree before running the ANOVA, thereby normalizing diameter measurements for different mortality rates in each field. The actual average density of willows was quite different between fields, after mortality suffered during dry conditions in the weeks following planting (almost $25 \%$ in Dry field, $\sim 15 \%$ in Sandy, and $\sim 5 \%$ in Rocky; but scattered enough in each field to be roughly equivalent across treatment combinations and blocks). Finally, because of fertilizer spillover from a nearby field during the third year, an entire row of the Sandy field had to be dropped from the analyses and the blocks in that field redrawn to maintain the correct number of each treatment combination (reducing the number of blocks in that field by four).

Growth was also measured in the second and third years by cutting down and weighing above-ground biomass, and reported as oven dry tons per hectare (ODT/ha). This was calculated from wet mass measurements taken in the field, using a conversion of 0.53 in 2011 and 0.61 in 2012, found from drying samples in the lab. The same density values for each field were then used to calculate per ha, as with SBA/ha.

In the model for our ANOVA, experimental blocks needed to be nested in the field, since block 1 of the Dry field was not the same as block 1 of the Sandy field, and so on. The model was modified accordingly, keeping a full-factorial combination of all variables besides those instances where field and (now nested) blocks were combined. Furthermore, all combinations of blocks had to be designated as random components, since they did not represent a variable we were interested in testing, but were necessary for the ANOVA to incorporate random heterogeneity within the fields. ANOVA residuals did indicate heteroscedasticity, which was corrected by logarithmic transforming our measured data.

\section{Results}

The experiment found no productivity difference between uninoculated and inoculated plantation willows. As Figure 1 shows, during the first 2 years, when the most trees were measured, no difference was shown between the observed results and inoculation treatment predicted mean SBA/ha values. Similarly, while the third year had fewer measured trees, and did seemingly see a small difference between SBA/ha mean predicted values, this difference was not statistically significant. This result held true whether tree height was measured, or whole trees were cut down and weighed (see Supplementary Material, Tables S1-S10). 


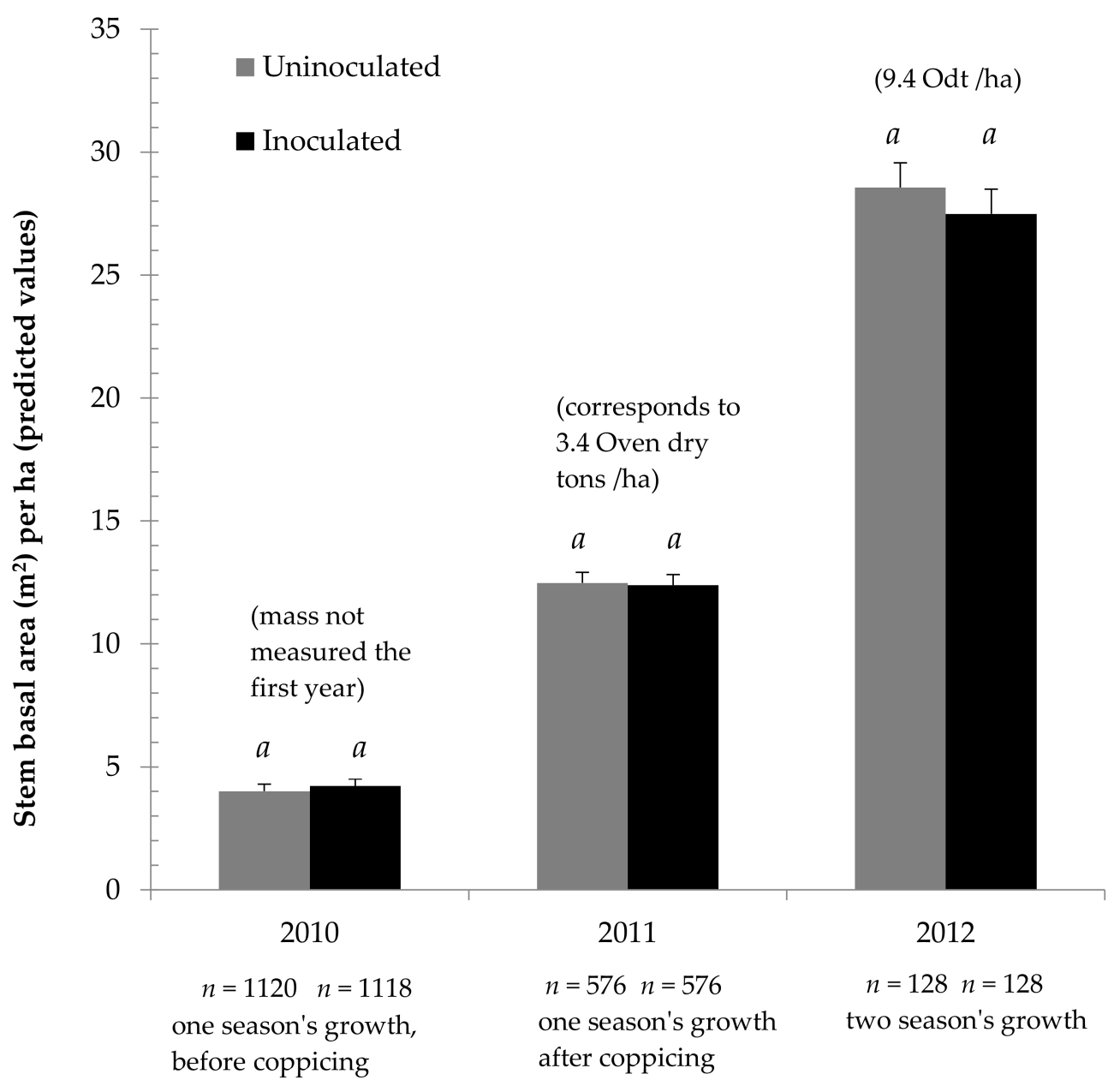

Figure 1. Cumulative growth of Salix miyabeana ('SX61' and 'SX64') during establishment on marginal land, treated with mycorrhizal inoculum. Error bars are standard error (SE). Within each year, similar letters $(a, b)$ above the bars indicate that the ANOVA did not find significant differences $(p<0.05)$ between predicted means for inoculation treatment.

Table 2 shows the results of the ANOVA on 2011 SBA/ha data in more depth. This ANOVA confirms that the field sites used were different enough to affect the willows' productivity, and that the nitrogen fertilization treatment was significant as well. Table 3 provides the effect size, showing that fertilization gave a predicted mean increase of $27 \%$ SBA/ha in 2011. Even more strikingly, the Sandy field showed a predicted mean increase of 55\% SBA/ha over the Rocky field in 2011. Similarly, significant biological and statistical effect sizes were seen in other years, and with the height and weight data, though fertilization was only applied in 2011, and therefore, showed less effect in 2012 (see Supplementary Material, Tables S1-S14). The overall patterns in Figure 1 and Tables 2 and 3 are representative of those seen over the three years, with height and weight as seen in the Supplementary Material (Tables S1-S10). As seen in Figure 2, the different fields did yield different results relative to one another. While the Sandy field showed markedly higher cumulative growth the first two years, cumulative growth in the Dry field caught up and equaled that of the Sandy field by the third year (Figure 2). 
Table 2. ANOVA of the effects of soil type, mycorrhizal inoculation and nitrogen fertilization on stem basal area/ha (LOG transformed) of willows after one season's growth in marginal land.

\begin{tabular}{cccccc}
\hline Source & Nparm & DF & DFDen & F Ratio & Prob $>\boldsymbol{F}$ \\
\hline Field & 2 & 2 & 33 & 21.0017 & $<0001^{*}$ \\
Inoc & 1 & 1 & 33 & 0.0175 & 0.8955 \\
Field $\times$ inoc & 2 & 2 & 33 & 1.1145 & 0.3401 \\
Fert & 1 & 1 & 33 & 105.1391 & $<0001^{*}$ \\
Field $\times$ fert & 2 & 2 & 33 & 1.8694 & 0.1702 \\
Inoc $\times$ fert & 1 & 1 & 33 & 0.0187 & 0.8920 \\
Field $\times$ inoc $\times$ fert & 2 & 2 & 33 & 0.2658 & 0.7682 \\
Cultivar & 1 & 1 & 33 & 0.0465 & 0.8305 \\
Field $\times$ cultivar & 2 & 2 & 33 & 0.4076 & 0.6686 \\
Inoc $\times$ cultivar & 1 & 1 & 33 & 0.8624 & 0.3598 \\
Field $\times$ inoc $\times$ cultivar & 2 & 2 & 33 & 0.2301 & 0.7957 \\
Fert $\times$ cultivar & 1 & 1 & 33 & 0.1629 & 0.6891 \\
Field $\times$ fert $\times$ cultivar & 2 & 2 & 33 & 0.4619 & 0.6341 \\
Inoc $\times$ fert $\times$ cultivar & 1 & 1 & 33 & 2.0731 & 0.1593 \\
Field $\times$ inoc $\times$ fert $\times$ cultivar & 2 & 2 & 33 & 0.602 & 0.5536 \\
\hline All
\end{tabular}

All combinations of the block treatment, by itself and with the other treatment variables, were part of the model. However, the block was treated differently since it was nested in the field variable, and labeled as a random attribute. Therefore, it does not appear in this table. An asterisk $(*)$ next to the $p$-value denotes a $5 \%$ statistical significance.

Table 3. Stem basal area per hectare $\left(\mathrm{m}^{2} / \mathrm{ha}\right)$ of willows after one season's growth in marginal land. ANOVA predicted values and a posteriori test results according to soil type, mycorrhizal inoculation, nitrogen fertilization or willow cultivar.

\begin{tabular}{cccc}
\hline $\begin{array}{c}\text { Experimental } \\
\text { Treatments }\end{array}$ & Least Squares Mean & Standard Error & Test \\
\hline & Panel A: Field & & Tukey's test \\
\hline Dry & 11.029889 & 0.66402733 & $\mathrm{~B}^{1}$ \\
Rocky & 10.307269 & 0.66402733 & $\mathrm{~B}$ \\
Sandy & 15.964387 & 0.66402733 & $\mathrm{~A}$ \\
\hline & Panel B: Inoculation ${ }^{1}$ & & Student's T-test \\
\hline Not inoculated & 12.478451 & 0.43045506 & $\mathrm{~A}$ \\
Inoculated & 12.389246 & 0.43045506 & $\mathrm{~A}$ \\
\hline & Panel C: Nitrogen fertilization & & Student's T-test \\
\hline Fertilized & 13.921206 & 0.4122257 & $\mathrm{~B}$ \\
\hline Unfertilized & 10.946491 & 0.4122257 & Student's T-test \\
\hline & Panel D: Cultivar & & $\mathrm{A}$ \\
'SX64' & 12.486569 & 0.44855227 & $\mathrm{~A}$ \\
\hline
\end{tabular}

${ }^{1}$ Different letters $(\mathrm{A}$ and $\mathrm{B})$ within each panel denote a significant $(\geq 0.05)$ difference between means. 


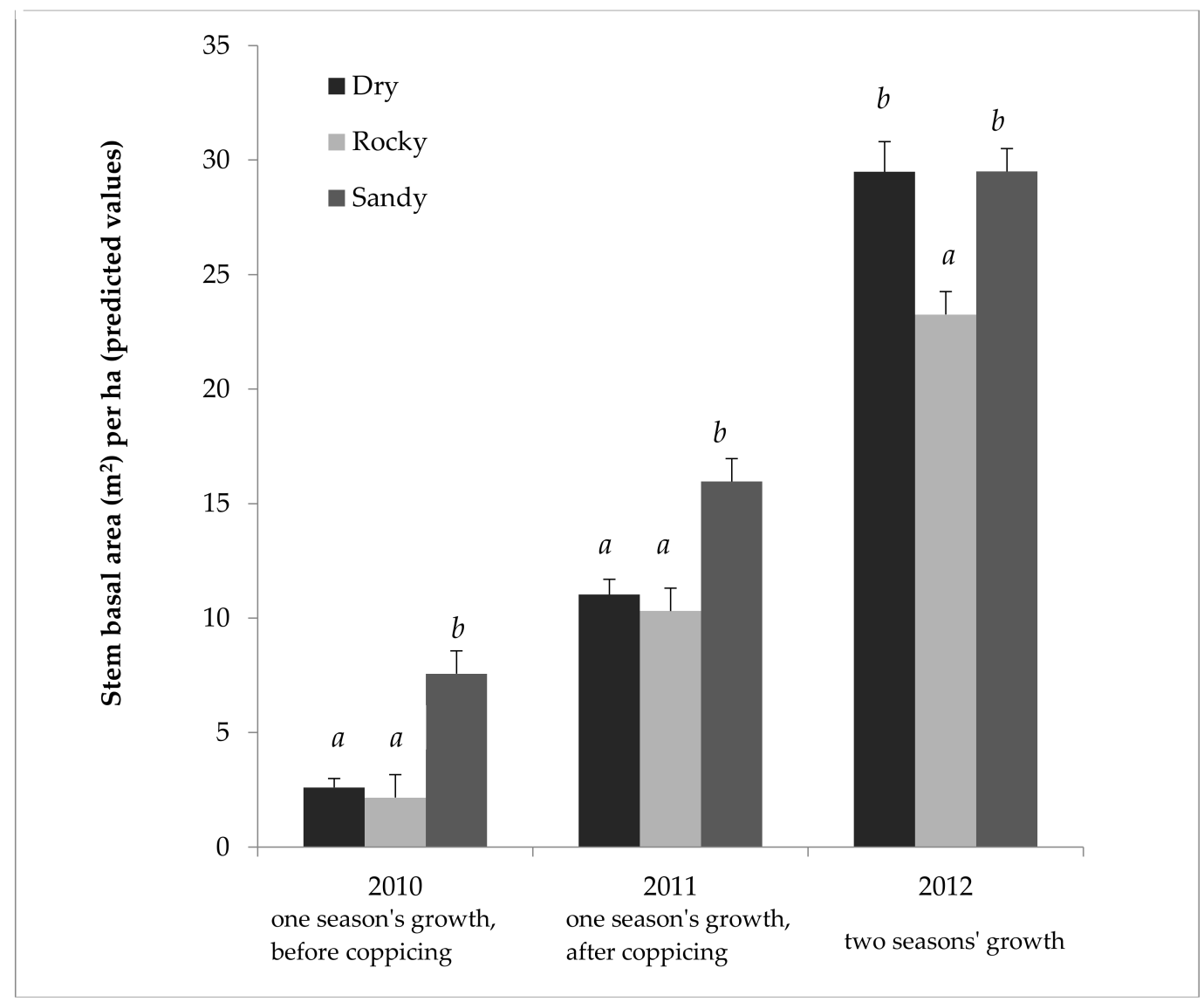

Figure 2. Cumulative growth of Salix miyabeana ('SX61' and 'SX64') during establishment on marginal land, in three different fields. Stem basal area predicted values (untransformed) and test results (LOG transformed) by field for all three years. Note: 2012 represents only one cultivar type ('SX61'), because of treatment interaction; however, 2010 and 2011 are the full model. Error bars are standard errors. Letters $(a, b)$ above the bars indicate that the Tukey's test found a significant difference $(p<0.05)$ between predicted means for each field (a separate analysis each year). $n=768$ each for Normal and Rocky fields in 2010; $n=704$ for Sandy field in 2010; $n=384$ in 2011 for each field; $n=96$ in 2012 for each field.

Figure 3 shows the effect of nitrogen fertilization on growth, using SBA/ha from 2011 and 2012 to illustrate the difference in effect in each year. Figure 4 shows the fertilization effect on mass, using ODT/ha (Oven dry tons per hectare), as opposed to SBA/ha. Figure 4 also focuses on 2011, the year of the main fertilization effect, and taking into account an interaction between field and fertilization as indicated by the ANOVA, breaks down the effect by field. The effect of fertilization is even more marked in this case, as fertilization gave a predicted mean increase of 51\% ODT/ha in 2011 in the Sandy field. 


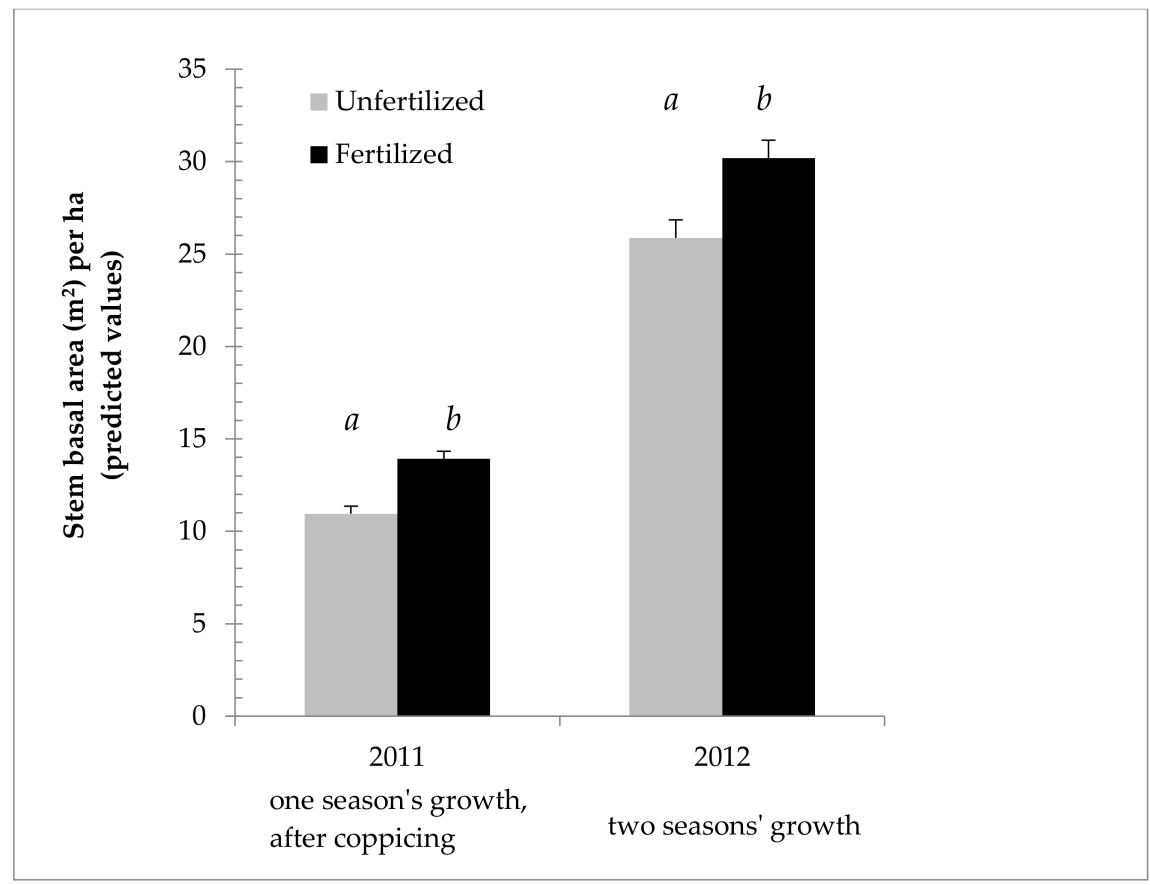

Figure 3. Cumulative growth of Salix miyabeana ('SX61' and 'SX64') during establishment on marginal land. Stem basal area predicted values (untransformed) and ANOVA results (LOG transformed) for the year in which fertilization treatment was applied (2011), as well as for the following year (past growth, plus any residual nitrogen in the soil). Note: Error bars are standard errors. Different letters (a, b) above the bars indicate a significant difference $(p<0.05) . n=576$ in 2011 for each fertilization treatment; $n=144$ in 2012 for each fertilization treatment.

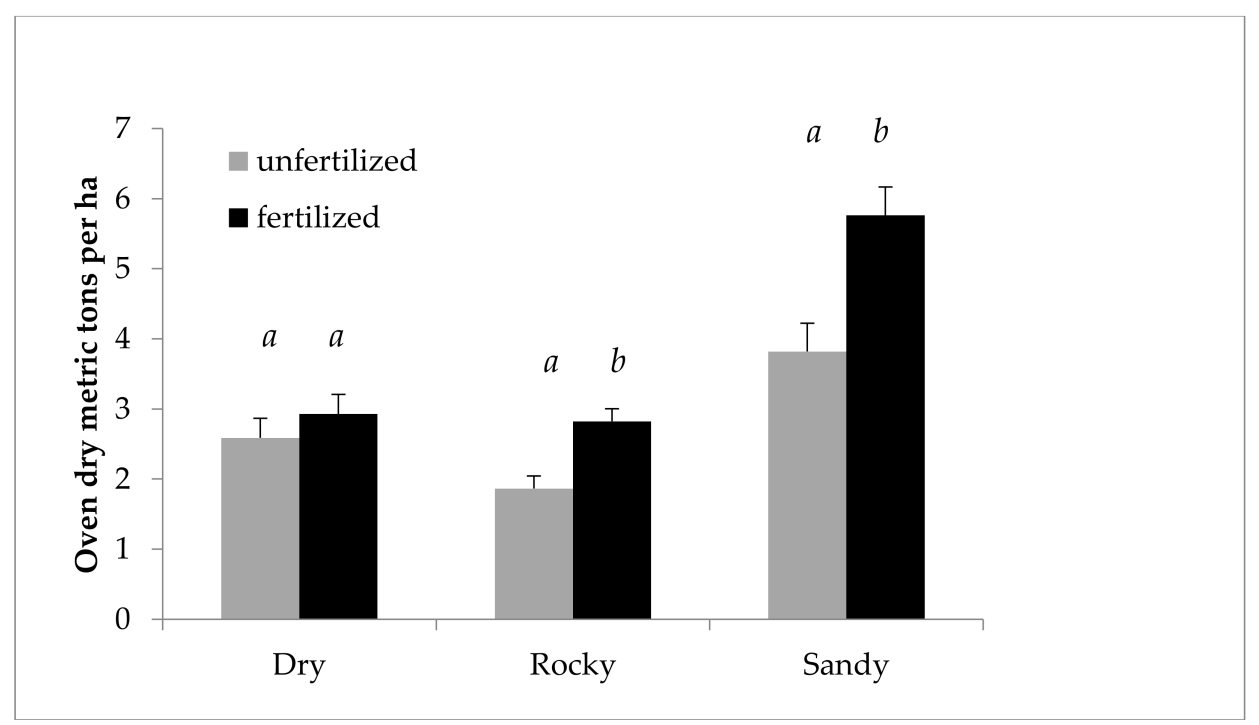

Figure 4. Cumulative growth of Salix miyabeana ('SX61' and 'SX64'). Oven dry tons per ha predicted values (untransformed) by field for 2011. Note: Error bars are standard errors. Different letters $(a, b)$ above the bars indicate a significant difference $(p<0.05)$. The ANOVA (performed on LOG transformed values), including all variables in the model, found a likely interaction between field and fertilization, prompting the breakdown by field. $n=192$ for each field and fertilization treatment. 


\subsection{Sequence Library Results}

Out of a total of 384 sequenced clones from $18 \mathrm{~S}$ amplicons, 269 were identified as AM sequences and were regrouped into eight OTUs at $98 \%$ similarity (Table 4 ). This represented $70 \%$ specificity for primers AML1 and AML2, nested following amplification with primers NS1 and NS41. Forty-three other OTUs were non-specific amplifications, 35 of them being from eukaryotic organisms. Wild AM fungi (in our uninoculated group) included three Diversispora OTUs, one OTU of the closely related Archeospora/Ambispora Ambispora, and three Glomeromycota. OTUs. The inoculum only added a single unique OTU, identified as uncultured Archaeospora with one sequence (possibly an artifact), but did appreciably increase the relative Glomus sequence numbers, nor did it eliminate the Diversispora numbers entirely. Also, somewhat surprisingly, the inoculum increased relative Ambispora sequence numbers.

Table 4. Arbuscular mycorrhizal sequences found in rhizosphere samples from biomass plantation willows after one season's growth in marginal land, by mycorrhizal inoculation treatment.

\begin{tabular}{cccc}
\hline OTU & Not Inoculated & Inoculated & Name and GI ${ }^{\mathbf{1}}$ of Closest Match in NCBI Database \\
\hline OTU-10 & 1 & - & Diversispora celata: 224586636 \\
OTU-11 & 32 & - & Diversispora sp. W4538: 342298391 \\
OTU-12 & 2 & - & Uncultured Diversispora: 398649715 \\
OTU-13 & 19 & 47 & Glomus sp. MC27: 334683211 \\
OTU-14 & 31 & 39 & Uncultured Glomus: 401664149 \\
OTU-15 & 10 & 78 & Uncultured Ambispora: 308084344 \\
OTU-16 & - & 1 & Uncultured Archaeospora: 308084350 \\
OTU-17 & 9 & - & Glomeromycota sp. MIB 8442: 328541374 \\
\hline
\end{tabular}

${ }^{1}$ GI: GenInfo Identifier.

The ITS sequences grouped into 40 OTUs at $98 \%$ similarity. Out of them, 16 OTUs represented two or more sequences, and encompassed almost $90 \%$ of the 288 total sequenced clones (Table 5). Five OTUs were mycorrhizal, according to NCBI database notes: Pulvinula (P.) constellation, Hymenogaster griseus, uncultured Sebacinales, uncultured ectomycorrhizal fungus, and uncultured Salix L. associated fungus. The inoculum did not have a clear effect, with P. constellatio increasing in number but the uncultured ectomycorrhizal fungus decreasing appreciably. The most numerous sequence, the uncultured Salix associated fungus, was unaffected. One OTU identified as Hebeloma (Fr.). cf. crustuliniforme was not labeled as EM in the NCBI notes, but is known to be ectomycorrhizal [43]. It was only present in the inoculated samples, and is so closely related to the inoculated EM species (Hebeloma longicaudum) that the five sequences found could very well be the inoculum detected in low numbers.

Table 5. Ectomycorrhizal sequences (and sequences of other fungi) found in rinsed root samples from biomass plantation willows after one season's growth in marginal land, by mycorrhizal inoculation treatment.

\begin{tabular}{ccccc}
\hline OTU & Not Inoculated & Inoculated & $\begin{array}{c}\text { Name and GI }{ }^{1} \text { of Closest Match in } \\
\text { NCBI Database }\end{array}$ & Phylum (Division) \\
\hline OTU-2 & 5 & 3 & Cladosporium cladosporioides: 356484684 & Ascomycota \\
OTU-3 & 2 & 2 & Epicoccum nigrum: 404474360 & Ascomycota \\
OTU-6 & 8 & 8 & Magnusiomyces 357934165 & Ascomycota \\
OTU-9 & 9 & 24 & $*$ Pulvinula constellatio: 10178659 & Ascomycota \\
OTU-11 & 2 & - & Trichurus spiralis: 237872399 & Ascomycota \\
OTU-17 & - & 2 & Uncultured Geopora: 295291451 & Ascomycota \\
OTU-18 & 2 & 2 & Uncultured Hyaloscyphaceae: 193850652 & Ascomycota \\
OTU-21 & - & 5 & Hebeloma crustuliniforme 2 UE-2011: 359751813 & Basidiomycota \\
\hline
\end{tabular}


Table 5. Cont.

\begin{tabular}{ccccc}
\hline OTU & Not Inoculated & Inoculated & $\begin{array}{c}\text { Name and GI }{ }^{\mathbf{1}} \text { of Closest Match in } \\
\text { NCBI Database }\end{array}$ & Phylum (Division) \\
\hline OTU-22 & - & 3 & ${ }^{2}$ Hymenogaster griseus: 387145960 & Basidiomycota \\
OTU-28 & 2 & - & Uncultured 334683052 & Basidiomycota \\
OTU-30 & 1 & 3 & * Uncultured Sebacinales: 264716693 & Basidiomycota \\
OTU-33 & 16 & 1 & ${ }^{*}$ Uncultured ectomycorrhizal fungus: 404247775 & unknown \\
OTU-34 & 71 & 70 & ${ }^{*}$ Uncultured fungus (from Salix rhiz. ${ }^{2}$ ): 402535072 & unknown \\
OTU-35 & 4 & 3 & Uncultured soil fungus: 195964332 & unknown \\
OTU-36 & 1 & 5 & Olpidium brassicae: 87159723 & unknown \\
OTU-40 & 2 & - & Entrophospora sp. JJ38: 15809596 & Glomeromycota \\
\hline
\end{tabular}

Names marked with an asterisk $\left(^{*}\right)$ are EM species according to NCBI entry notes. ${ }^{1}$ GI: GenInfo Identifier; 2 rhizosphere.

\section{Discussion}

Willow growers with access to marginal land should be interested in our data, as it represents farm-scale, real-world results across different field types, both with and without nitrogen fertilization. The success of the less drained, wetter Sandy field is promising for those with similar land, though the apparent early growth benefit in the Sandy field could simply have resulted from the more clay-rich Dry and Rocky fields being harder for the willow roots to penetrate. At the very least, a farmer with a rock-strewn, clay-heavy field like our Rocky field might decide not to try cultivating willows after seeing our results, especially if it is deficient in phosphorous minerals (as ours was). Likewise, a farmer might try to reduce fertilizer costs (or to minimize the climate impacting effect of such fertilizers), given that our data indicates that a $51 \%$ increase in growth is possible in particular fields with a fairly modest nitrogen addition $(75 \mathrm{~kg} / \mathrm{ha})$. However, although such results are of interest, they must be seen as ancillary to those concerning inoculation. The entire design of the experiment was geared towards studying the effect of inoculation. Field selection and characterization, as well as fertilization treatment, were chosen to test inoculation rather than drainage or fertilizer effect per se. Neither drainage nor fertilization were monitored in a sufficiently systematic manner as to allow us to ascertain their effects across different treatment values, or the upper and lower bounds.

The likeliest conclusion to draw from the experiment is that inoculation with the two mycorrhizal species used, $R$. irregulare and $H$. longicaudum, does not appreciably benefit the growth of biomass willows cultivated in marginal agricultural fields. Neither cultivar of willow tested showed a significant difference across inoculation treatments. Neither did the full factorial ANOVA show any mixed effects between inoculation and field site, or inoculation and fertilization treatment. So, inoculation was not shown to be of benefit within even one of the tested ranges of soil/fertility conditions.

The AM species used, R. irregulare, has been shown to benefit willow growth [17] in sterile soil greenhouse experiments. That it did not behave in this manner in this experiment strongly suggests that wild mycorrhizal species mask the treatment. In fact, several wild AM species were found (Table 4), as well as several wild probable EM species (Table 5). This is not that surprising, as corn and soybean crops that would have been present in previous years could host AM species. Annual monocrop systems are not ideal for diverse mycorrhizal communities [44], but many AM species are known to survive $[45,46]$. Such wild strains could benefit uninoculated control willows just as much as the inoculum might benefit treatment willows, or even outcompete the inoculum strain with the same result. The wild EM species are more unexpected however, since willow specific EM fungi are not likely to be associated with annual agricultural crops [47]. In this case though, wild willows bordered the sandy site, and all three sites were fairly close (within a quarter $\mathrm{km}$ ) of established willow plantations. Such locally adapted, willow-specific EM strains could easily have outcompeted with, or masked, the introduced strain.

The pooled sequence libraries for the inoculation treatments do indicate that the inoculum was viable and competitive enough to be detected after the first year of growth in the field (the possibility that it was not had to be considered as an alternative hypothesis to explain the data). Furthermore, 
viability of the inoculum was confirmed with a small greenhouse test, as mentioned in the methods. The AM species (Table 4) were present at roughly twice the numbers of those of the relative Glomus species in the inoculated plots. The EM species (Table 5) are more difficult to interpret, but there were some Hebeloma sequences in the treated plots that were not present in the untreated plots.

The experimental results suggest that inoculation with AM fungi in general will not benefit willows grown in agricultural settings, as such willows already have the potential to interact with numerous, wild AM strains. A diversity of AM species appears to be ubiquitous to different degrees in agricultural soil [46].

However, we cannot conclude that another strain of EM fungi would not benefit willows grown in such a setting. The Hebeloma species selected has been shown to be associated with a very closely related species of tree (Populus), but greenhouse or pot experiments to confirm positive interaction with biomass willows had not been conducted prior to this experiment. Not many EM fungi are commercially available in the quantities needed in an agricultural setting, and the EM inoculum was the only one available at the time of our experiment's setup. Because EM fungi are more host specific than AM fungi [48,49], and are less likely to be present in agricultural fields [50,51], we encourage researchers to test other species and strains as they become available for agricultural applications.

For willow growers, our results caution against investing in mycorrhizal inoculation, unless a strain has proven to be beneficial in field tests with willows (or in pot tests using unsterilized farm soil). We would still advise growers to apply mycorrhizal inoculation if planting on semi-sterile soil, such as heavily fungicide-applied sands, mine tailings, etc. However, our results suggest that such an inoculation could simply be a diluted soil slurry from a healthy agricultural field nearby.

Supplementary Materials: The following are available online at http:/ /www.mdpi.com/1999-4907/9/4/185/s1, Table S1: 2010 Height ANOVA results (LOG transformed), Table S2: 2010 Height $(\mathrm{cm})$ ANOVA predicted values and test results, Table S3: 2011 Height ANOVA results (LOG transformed), Table S4: 2011 Height (cm) ANOVA predicted values and test results, Table S5: 2012 Height ANOVA results (LOG transformed), Table S6: 2012 Height cm ANOVA predicted values and test results, Table S7: 2011 Oven dry tons / ha ANOVA results (LOG transformed), Table S8: 2011 Oven dry tons /ha ANOVA predicted values and test results, Table S9: 2012 Oven dry tons /ha ANOVA results (LOG transformed), Table S10: 2012 Oven dry tons / ha ANOVA predicted values and test results, Table S11: 2010 Stem basal area ANOVA results (LOG transformed), Table S12: 2010 Stem basal area per hectare $\left(\mathrm{m}^{2} / \mathrm{ha}\right)$ ANOVA predicted values and test results, Table S13: 2012 Stem basal area ANOVA results (LOG transformed), Table S14: 2012 Stem basal area per hectare $\left(\mathrm{m}^{2} / \mathrm{ha}\right.$ ) ANOVA predicted values and test results, Figure S1: Experimental design (each field randomized according to the schema, rocky field shown as an example). Widths compressed substantially compared to heights to fit on page; actual measurements given on side and top of plan. B refers to block; F to fertilization; $\mathrm{M}$ to inoculation. + sign means the subplot was fertilized or inoculated; - sign that it was not. SM stands for cultivar Salix miyabeana 'SX61', SS for cultivar 'SX64'.

Acknowledgments: This study was conducted with the financial assistance of Agri-Food Innovation Support Program of the Quebec Ministry of Agriculture, Fisheries and Food. The authors gratefully thank Agro Énergie for their valuable collaboration and Stéphane Daigle for his assistance in the statistical analyses.

Author Contributions: M.S.-A., M.L., and T.J.P. conceived and designed the experiments; T.J.P. performed the experiments; T.J.P. analyzed the data; M.S.-A. contributed reagents, materials, and analysis tools; T.J.P. wrote the paper; W.G.N. provided extensive proof-reading and suggested edits.

Conflicts of Interest: The authors declare no conflict of interest.

\section{References}

1. Liu, T.; Ma, Z.; McConkey, B.; Kulshreshtha, S.; Huffman, T.; Green, M.; Liu, J.; Du, Y.; Shang, J. Bioenergy production on marginal land in Canada: Potential, economic feasibility, and greenhouse gas emissions impacts. Appl. Energy 2017, 205, 477-485. [CrossRef]

2. Don, A.; Osborne, B.; Hastings, A.; Skiba, U.; Carter, M.S.; Drewer, J.; Flessa, H.; Freibauer, A.; Hyvönen, N.; Jones, M.B.; et al. Land-use change to bioenergy production in Europe: Implications for the greenhouse gas balance and soil carbon. GCB Bioenergy 2012, 4, 372-391. [CrossRef]

3. Labrecque, M.; Teodorescu, T.I. Influence of plantation site and wastewater sludge fertilization on the performance and foliar nutrient status of two willow species grown under SRIC in southern Quebec (Canada). For. Ecol. Manag. 2001, 150, 223-239. [CrossRef] 
4. Guidi, W.; Pitre, F.; Labrecque, M. Short-rotation coppice of willows for the production of biomass in Eastern Canada. In Biomass Now-Sustainable Growth and Use; Matovic, M.D., Ed.; InTech Open Science: Rijeka, Croatia, 2013; pp. 421-448.

5. Kopp, R.F.; White, E.H.; Abrahamson, L.P.; Nowak, C.A.; Zsuffa, L.; Burns, K.F. Willow biomass trials in Central New York State. Biomass Bioenergy 1993, 5, 179-187. [CrossRef]

6. Buchholz, T.; Volk, T. Improving the profitability of willow crops-Identifying opportunities with a crop budget model. Bioenergy Res. 2011, 4, 85-95. [CrossRef]

7. Caslin, B.; Finnan, J.; McCracken, A. Short Rotation Coppice Willow Best Practice Guidelines; AFBI Agri-Food \& Bioscience Institute: Belfast, England, 2010.

8. Wang, B.; Qiu, Y.L. Phylogenetic distribution and evolution of mycorrhizas in land plants. Mycorrhiza 2006, 16, 299-363. [CrossRef] [PubMed]

9. Whiteside, M.D.; Digman, M.A.; Gratton, E.; Treseder, K.K. Organic nitrogen uptake by arbuscular mycorrhizal fungi in a boreal forest. Soil Biol. Biochem. 2012, 22, 7-13. [CrossRef] [PubMed]

10. Smith, S.E.; Jakobsen, I.; Grønlund, M.; Smith, F.A. Roles of arbuscular mycorrhizas in plant phosphorus nutrition: Interactions between pathways of phosphorus uptake in arbuscular mycorrhizal roots have important implications for understanding and manipulating plant phosphorus acquisition. Plant Physiol. 2011, 156, 1050-1057. [CrossRef] [PubMed]

11. Liu, J.; Maldonado-Mendoza, I.; Lopez-Meyer, M.; Cheung, F.; Town, C.D.; Harrison, M.J. Arbuscular mycorrhizal symbiosis is accompanied by local and systemic alterations in gene expression and an increase in disease resistance in the shoots. Plant J. 2007, 50, 529-544. [CrossRef] [PubMed]

12. St-Arnaud, M.; Vujanovic, V. Effect of the arbuscular mycorrhizal symbiosis on plant diseases and pests. In Mycorrhizae in Crop Production; Hamel, C., Plenchette, C., Eds.; Haworth Food \& Agricultural Products Press: Binghamton, NY, USA, 2007; pp. 67-122.

13. Lekberg, Y.; Koide, R.T. Is plant performance limited by abundance of arbuscular mycorrhizal fungi? A meta-analysis of studies published between 1988 and 2003. New Phytol. 2005, 168, 189-204. [CrossRef] [PubMed]

14. Puettsepp, U.; Rosling, A.; Taylor, A.F.S. Ectomycorrhizal fungal communities associated with Salix viminalis L. and S. dasyclados Wimm. clones in a short-rotation forestry plantation. For. Ecol. Manag. 2004, 196, 413-424. [CrossRef]

15. Paradi, I.; Baar, J. Mycorrhizal fungal diversity in willow forests of different age along the river Waal, The Netherlands. For. Ecol. Manag. 2006, 237, 366-372. [CrossRef]

16. Ryberg, M.; Andreasen, M.; Bjoerk, R.J. Weak habitat specificity in ectomycorrhizal communities associated with Salix herbacea and Salix polaris in alpine tundra. Mycorrhiza 2011, 21, 289-296. [CrossRef] [PubMed]

17. Van der Heijden, E.W. Differential benefits of arbuscular mycorrhizal and ectomycorrhizal infection of Salix repens. Mycorrhiza 2001, 10, 185-193. [CrossRef]

18. Hashimoto, Y.; Higuchi, R. Ectomycorrhizal and arbuscular mycorrhizal colonization of two species of floodplain willows. Mycoscience 2003, 44, 339-343. [CrossRef]

19. Milne, J.M.; Ennos, R.A.; Holingsworth, R.M. Vegetation influence on ectomycorrhizal inoculum available to sub-arctic willow (Salix lapponum L.) planted in an upland site. Bot. J. Scotl. 2006, 58, 19-34. [CrossRef]

20. Becerra, A.G.; Nouhra, E.R.; Silva, M.P.; McKay, D. Ectomycorrhizae, arbuscular mycorrhizae, and dark-septate fungi on Salix humboldtiana in two riparian populations from central Argentina. Mycoscience 2009, 50, 343-352. [CrossRef]

21. Baxter, J.W.; Dighton, J. Ectomycorrhizal diversity alters growth and nutrient acquisition of grey birch (Betula populifolia) seedlings in host-symbiont culture conditions. New Phytol. 2001, 152, 139-149. [CrossRef]

22. Fransson, P.M.A.; Toljander, Y.K.; Baum, C.; Weih, M. Host plant-ectomycorrhizal fungus combination drives resource allocation in willow: Evidence for complex species interaction from a simple experiment. Ecoscience 2013, 20, 112-121. [CrossRef]

23. Corredor, A.H.; van Rees, K.; Vujanovic, V. Changes in root-associated fungal assemblages within newly established clonal biomass plantations of Salix spp. For. Ecol. Manag. 2012, 282, 105-114. [CrossRef]

24. Six, J.; Frey, S.D.; Thiet, R.K.; Batten, K.M. Bacterial and fungal contributions to carbon sequestration in agroecosystems. Soil Sci. Soc. Am. 2006, 70, 556-569. [CrossRef] 
25. Douds, D.D.; Nagahashi, G.; Shenk, J.E. Frequent cultivation prior to planting to prevent weed competition results in an opportunity for the use of arbuscular mycorrhizal fungus inoculum. Renew. Agric. Food Syst. 2012, 27, 251-255. [CrossRef]

26. Garbaye, J.; Churin, J.L. Growth stimulation of young oak plantations inoculated with the ectomycorrhizal fungus Paxillus involutus with special reference to summer drought. For. Ecol. Manag. 1997, 98, 221-228. [CrossRef]

27. Baum, C.; Stetter, U.; Makeschin, F. Growth response of Populus trichocarpa to inoculation by the ectomycorrhizal fungus Laccaria laccata in a pot and a field experiment. For. Ecol. Manag. 2002, 163, 1-8. [CrossRef]

28. Duponnois, R.; Plenchette, C.; Prin, Y.; Ducousso, M.; Kisa, M.; Bâ, A.M.; Galiana, A. Use of mycorrhizal inoculation to improve reafforestation process with Australian Acacia in Sahelian ecozones. Ecol. Eng. 2007, 29, 105-112. [CrossRef]

29. Quoreshi, A.M.; Piché, Y.; Khasa, D.P. Field performance of conifer and hardwood species 5 years after nursery inoculation in the Canadian Prairie Provinces. New For. 2008, 35, 235-253. [CrossRef]

30. Chapdelaine, A.; Dalpé, Y.; Hamel, C.; St Arnaud, M. Arbuscular mycorrhizal inoculation of ornamental trees in nursery. In Mycorrhiza Works; Feldmann, F., Kapulnik, Y., Baar, J., Eds.; Deutsche Phytomedizinische Gesellschaft, Spectrum Phytomedizin: Braunschweig, Germany, 2008; pp. 46-55. ISBN 978-3-941261-01-3.

31. Quoreshi, A.M.; Khasa, D.P. Effectiveness of mycorrhizal inoculation in the nursery on root colonization, growth, and nutrient uptake of aspen and balsam poplar. Biomass Bioenergy 2008, 32, 381-391. [CrossRef]

32. Fillion, M.; Brisson, J.; Guidi, W.; Labrecque, M. Increasing phosphorus removal in willow and poplar vegetation filters using arbuscular mycorrhizal fungi. Ecol. Eng. 2011, 37, 199-205. [CrossRef]

33. Bissonnette, L.; St-Arnaud, M.; Labrecque, M. Phytoextraction of heavy metals by two Salicaceae clones in symbiosis with arbuscular mycorrhizal fungi during the second year of a field trial. Plant Soil 2010, 332, 55-67. [CrossRef]

34. Sieverding, E.; da Silva, G.A.; Berndt, R.; Oehl, F. Rhizoglomus, a new genus of the Glomeraceae. Mycotaxon 2015, 129, 373-386. [CrossRef]

35. Stockinger, H.; Walker, C.; Schüßler, A. Glomus intraradices DAOM197198, a model fungus in arbuscular mycorrhiza research, is not Glomus intraradices. New Phytol. 2009, 183, 1176-1187. [CrossRef] [PubMed]

36. Conseil de Production Végétale du Québec. Méthodes D'analyse des Sols, des Fumiers et des Tissus Végétaux; Ministère de l'Agriculture, des Pêcheries et de l'Alimentation. Gouvernement du Québec: Ste-Foy, QC, Canada, 1998. (In French)

37. U.S. Environmental Protection Agency. Method 200.7. Inductively coupled plasma-atomic emission spectrometric method for trace element analysis of water and waste. In Methods for Chemical Analysis of Water and Wastes; U.S. Environmental Protection Agency: Cincmnati, OH, USA, 1983; EPA-600/4-79-020.

38. Lee, J.; Lee, S.; Young, J.P. Improved primers for the detection and identification of arbuscular mycorrhizal fungi. FEMS Microb. Ecol. 2008, 65, 339-349. [CrossRef] [PubMed]

39. Ghannoum, M.A.; Jurevic, R.J.; Mukherjee, P.K.; Cui, F.; Sikaroodi, M.; Naqvi, A.; Gillevet, P.M. Characterization of the oral fungal microbiome (mycobiome) in healthy individuals. PLoS Pathog 2010, 6, e1000713. [CrossRef] [PubMed]

40. Hassan, S.E.; Boon, E.; St-Arnaud, M.; Hijri, M. Molecular biodiversity of arbuscular mycorrhizal fungi in heavy metal polluted soils. Mol. Ecol. 2011, 20, 3469-3483. [CrossRef] [PubMed]

41. Bell, T.H.; Hassan, S.E.; Lauron-Moreau, A.; Al Otaibi, F.; Hijri, M.; Yergeau, E.; St-Arnaud, M. Linkage between bacterial and fungal rhizosphere communities in hydrocarbon-contaminated soils is related to plant phylogeny. ISME J. 2014, 8, 331-343. [CrossRef] [PubMed]

42. McKnight, J.S. Black Willow (Salix nigra) Marsh. Available online: http://vmpincel.ou.edu/oliver/pdf/ Salix_nigraBlackWillow.pdf (accessed on 30 March 2018).

43. Aanen, D.K.; Kuyper, T.; Mes, T.H.M.; Hoekstra, R. The evolution of reproductive isolation in the ectomycorrhizal Hebeloma crustuliniforme aggregate (basidiomycetes) in northwestern Europe: A phylogenetic approach. Evolution 2000, 54, 1192-1206. [CrossRef] [PubMed]

44. Verbruggen, E.; Kiers, T.E. Evolutionary ecology of mycorrhizal functional diversity in agricultural systems. Evolut. Appl. 2010, 3, 547-560. [CrossRef] [PubMed] 
45. Beauregard, M.S.; Hamel, C.; Gauthier, M.P.; Zhang, T.; Tan, C.S.; Welacky, T.; St-Arnaud, M. Various forms of organic and inorganic P fertilizers did not negatively affect AM fungi communities and biomass in a maize-soybean rotation system. Mycorrhiza 2013, 23, 143-154. [CrossRef] [PubMed]

46. Moebius-Clune, D.J.; Moebius-Clune, B.N.; van Es, H.M.; Pawlowska, T.E. Arbuscular mycorrhizal fungi associated with a single agronomic plant host across the landscape: Community differentiation along a soil textural gradient. Soil Biol. Biochem. 2013, 64, 191-199. [CrossRef]

47. Tedersoo, L.; May, T.W.; Smith, M.E. Ectomycorrhizal lifestyle in fungi: Global diversity, distribution, and evolution of phylogenetic lineages. Mycorrhiza 2010, 20, 217-263. [CrossRef] [PubMed]

48. Newton, A.C.; Haigh, J.M. Diversity of ectomycorrhizal fungi in Britain: A test of the species-area relationship, and the role of host specificity. New Phytol. 1998, 138, 619-627. [CrossRef]

49. Kilronomos, J.N. Host-specificity and functional diversity among arbuscular mycorrhizal fungi. Microb. Biosyst. N. Front. 2000, 1, 845-851.

50. Dickie, I.A.; Reich, P.B. Ectomycorrhizal fungal communities at forest edges. J. Ecol. 2005, 93, $244-255$. [CrossRef]

51. Oehl, F.; Sieverding, E.; Ineichen, K.; Mäder, P.; Boller, T.; Wiemken, A. Impact of land use intensity on the species diversity of arbuscular mycorrhizal fungi in agroecosystems of Central Europe. Appl. Environ. Microbiol. 2003, 69, 2816-2824. [CrossRef] [PubMed]

(C) 2018 by the authors. Licensee MDPI, Basel, Switzerland. This article is an open access article distributed under the terms and conditions of the Creative Commons Attribution (CC BY) license (http://creativecommons.org/licenses/by/4.0/). 